\title{
Zagadnienie złożoności w teorii architektury końca XX wieku
}

\section{Complexity in late twentieth century theory of architecture}

\section{Streszczenie}

Postmodernizm podniósł rangę pojęcia złożoności, które stało się kluczowe dla teorii architektury XX wieku. Niezależnie przez pół stulecia rozwijały się interdyscyplinarne nauki o złożoności. Praca śledzi związki obu dziedzin, zwracając uwagę m.in. na wspólne źródła (teorię systemów złożonych Herberta A. Simona, z którego prac korzystali Robert Venturi i Christopher Alexander) oraz teoretyków architektury wyraźnie czerpiących z nauk o złożoności (m.in. Lucien Kroll, Nikos Salingaros).

Słowa kluczowe: złożoność, prostota, architektura, urbanistyka, filozofia, teoria architektury, postmodernizm, Robert Venturi, Christopher Alexander, Herbert A. Simon

Abstract

Postmodernism established the term 'complexity' as crucial for the twentieth century theory of architecture. Interdisciplinary complexity sciences developed independently throughout half of the century. The article tracks down relationships between the two, highlighting, among others, common genesis (Herbert A. Simon's complex systems theory, adopted by Robert Venturi and Christopher Alexander) and theorists depending heavily on complexity sciences (eg. Lucien Kroll or Nikos Salingaros).

Keywords: complexity, simplicity, architecture, urbanism, philosophy, theory of architecture, postmodernism, Robert Venturi, Christopher Alexander, Herbert A. Simon 


\section{WSTĘP}

Dychotomia prostoty i złożoności była jednym z najczęściej powtarzających się wątków debaty architektonicznej XX wieku. Spór modernizmu z postmodernizmem, zarówno w teorii, jak i w praktyce, przebiegał nieraz po linii wyznaczonej przez te dwie kategorie. Sztandarowym punktem programu modernizmu było ogólnie ujmowane „uproszczenie”: nie tylko poprzez folgowanie domniemanemu umiłowaniu człowieka do idealnych form euklidesowych, ale przede wszystkim poprzez idee automatyzacji produkcji, standaryzacji i zasadniczego ujęcia architektury w kategoriach maszyny ${ }^{1}$. Tak jak manifestem wyrażającym te idee najpełniej jest $W$ stronę architektury Corbusiera (1923), tak najmocniejszą odpowiedzią nań, rozpoczynającą w pełni erę postmodernizmu w architekturze, jest przełomowy esej Roberta Venturiego Complexity and Contradiction in Architecture (pl. Złożoność i sprzeczność w architekturze, 1966). Tekst ten uznawany jest za jedno z najtrafniejszych wyrażeń ducha tamtych czasów, stojących pod znakiem rewolucji przeciw modernizmowi, zaś obrona złożoności w architekturze stanowi jego główną i najważniejszą tezę. Jest to motyw przewijający się przez całą literaturę postmodernistyczną, w której nacisk stawia się na różnorodność, wielowarstwowość i mnogość czynników wpływających na jakość budynków i miast, przeciwstawiając to podejście nieuzasadnionym uproszczeniom modernizmu.

Teoria postmodernizmu w architekturze nie powstawała jednak w pustce. Dwudziestolecie powojenne było okresem wzmożonej aktywności naukowej i filozoficznej, mającej swoje korzenie w przełomowych odkryciach fizyki i matematyki pierwszej połowy XX wieku, które wymuszały nowe sposoby myślenia i opisywania rzeczywistości. Jednym z interesujących tropów jest wczesny związek postmodernizmu z rodzącymi się w tym samym okresie, a obecnie stanowiącymi rozległą i żywotną dyscyplinę naukami o złożoności (ang. complexity sciences). Do pewnego stopnia mają one z postmodernizmem wspólną genezę. Już pierwszy paragraf dzieła Venturiego, znany z otwierających go słów „lubię złożoność i sprzeczność w architekturze”, kończy się uwagą na temat powszechnego „uznania” złożoności w niemal wszystkich dziedzinach poza architekturą?

Wśród pozycji bibliograficznych, na które powołuje się Venturi (w większości autorstwa architektów i teoretyków architektury) zwraca uwagę The Architecture of Complexity (pl. Architektura złożoności, 1962) amerykańskiego ekonomisty Herberta A. Simona, będącego jednym z pionierów teorii systemów złożonych. Simon jako jeden z pierwszych wyróżnił cechy systemów złożonych, co stanowiło jedną z podstaw nowej, szerokiej nauki na temat podejmowania decyzji (ang. decision-making), a w konsekwencji stanowiło ważny przyczynek do teorii sztucznej inteligencji, za wkład w którą w 1975 roku został uhonorowany Nagrodą Turinga ${ }^{3}$. Na jego pracę licznie powoływał się architekt i matematyk Christopher Alexander w Notes on the Synthesis of Form (pl. Uwagi o Syntezie For$m y, 1964)$, pracy również cytowanej przez Venturiego ${ }^{4}$. Dyskutując więc o Complexity and Contradiction..., tekście mającym nieoceniony wręcz wpływ na całą późniejszą literaturę 
postmodernistyczną, trzeba zakładać, że autor znał wczesną teorię systemów złożonych i przynajmniej do pewnego stopnia posługiwał się kluczowym terminem „złożoność” właśnie w znaczeniu przez nią zdefiniowanym.

\section{ZŁOŻONOŚĆ W ZNACZENIU SYSTEMÓW ZŁOŻONYCH - HERBERT A. SIMON, CHRISTOPHER ALEXANDER}

W The Architecture of Complexity Herbert A. Simon podejmował dyskusję na temat głośnej wówczas idei „ogólnej teorii systemów”, która „abstrahując od właściwości charakterystycznych dla systemów fizycznych, biologicznych lub społecznych, miałaby zastosowanie do nich wszystkich" ${ }^{5}$. Obiektem jego zainteresowań były systemy złożone, a więc takie zjawiska i procesy, które składają się z wielu elementów oddziałujących na siebie wzajemnie w sposób nieprosty (ang. nonsimple) ${ }^{6}$. Zauważył, że gdyby modelować i opisywać takie systemy abstrakcyjnie, prezentują one pewne wspólne właściwości:

1) Hierarchiczność. Systemy złożone składają się z podsystemów, które z kolei składają się ze swoich podsystemów itd. Jako przykład takiego systemu podaje np. ludzkie ciało, gdzie komórki zorganizowane są w tkanki, tkanki w organy, organy w układy itd. Innymi przykładami są struktury mikroskopowe, kosmiczne albo organizacje społeczne.

2) Ewolucyjność. System hierarchiczny będzie adaptował się szybciej niż system niezorganizowany hierarchicznie. Simon wskazuje tym samym na ewolucyjną przewagę systemów złożonych nad niezłożonymi, czym uzasadnia ich powszechność - wypierają one w toku ewolucji swoich niezłożonych konkurentów.

3) Podatność na dekompozycję. W systemie złożonym poszczególne podsystemy działają względnie niezależnie od siebie nawzajem, co umożliwia sprawne funkcjonowanie całości, szybką korektę błędów (adaptację) w toku ewolucji oraz ułatwia zrozumienie ich struktury. Przykładowo w organizacji społecznej żaden jej członek nie ma równego wpływu na wszystkich pozostałych - pozostaje w stałym związku ze swoim departamentem lub wydziałem („podsystemem”) i ma pewien ograniczony wpływ na swoich podwykonawców i bezpośrednich przełożonych (poziomy sąsiadujące w hierarchii z jego własnym). Będzie mu jednak coraz trudniej mieć wpływ na decyzje podejmowane na dalszych poziomach hierarchii (np. przez przełożonych swoich przełożonych).

4) Możliwość opisu w sposób statyczny i dynamiczny. Każdy system złożony daje się opisać w kategoriach statycznych (w uproszczeniu - jako zjawisko) lub dynamicznych (jako proces prowadzący do zaistnienia zjawiska). Na przykład wspomniane już ciało ludzkie jest zjawiskiem złożonym, ale ewolucja, w wyniku której powstało, jest złożonym procesem.

Pierwsze trzy cechy odnoszą się zarówno do zjawisk, jak i procesów złożonych, gdzie hierarchiczność procesów objawia się, w dużym uproszczeniu, w istnieniu etapów, na które składają się inne etapy. Choć systemów złożonych jest w świecie dużo (co wynika zdaniem 
Simona ze wspomnianej przewagi ewolucyjnej), to jednocześnie podkreśla on, że nie są one jedynym sposobem, w jaki dają modelować się zjawiska. Przywołuje systemy o „płaskiej” hierarchii, które można by nazwać prostymi (np. diament złożony z niezliczonej liczby identycznych cząstek), albo takie o zachowaniu lub strukturze losowej (np. gazy) ${ }^{8}$. Tym samym złożoność dowolnego systemu nie jest oczywistością. Badanie zjawisk i procesów pod kątem występowania w nich np. odpowiedniej hierarchii może doprowadzić do odkrycia w nich innych, nietrywialnych właściwości typowych dla systemów złożonych.

Już dwa lata później argumenty za analizą architektury w kategoriach systemów złożonych podał Christopher Alexander w Notes on the Synthesis of Form. Ośrodkiem jego zainteresowań było budownictwo kultur, w których architektura nie wykształciła się jeszcze jako odrębna dziedzina. Udowadniał, że tradycja architektoniczna, rozumiana jako zbiór zasad kształtowania środowiska przestrzennego w obrębie kultury nieformalnej ${ }^{9}$, ma wszelkie cechy systemu złożonego, powstającego w wyniku ewolucyjnego procesu złożonego. Dlatego, jak argumentował, jedną z kluczowych cech tradycji jest jej homeostatyczność - zdolność do „naprawiania się" w toku ewolucji poprzez adaptację przy jednoczesnym zachowaniu tożsamości ${ }^{10}$.

Zasługą Alexandra było zauważenie, że same problemy projektowe są problemami o cechach złożonych - są złożone z licznych mniejszych problemów uporządkowanych hierarchicznie i poddają się dekompozycji ${ }^{11}$. Jako takie mogą być rozwiązywane tylko przez złożone rozwiązania. Tym samym postawił złożoność projektu architektonicznego w centrum zainteresowania teorii postmodernizmu - to ten trop podjął później i twórczo rozwinął Venturi w swoim opus magnum. Alexander argumentował, że tradycje architektury nieformalnej mają tę fundamentalną przewagę nad architekturą XX wieku, że same ewoluowały niejako równolegle z powolną ewolucją złożonych problemów przestrzennych i tym samym znajdowały nań najlepsze rozwiązania. W związku z przyspieszeniem demograficznym i technologicznym, nagłym spiętrzeniem się nowych problemów i szkodą, jaką wyrządził modernizm poprzez nadmierne uproszczenia w dziedzinie architektury, zaistniała potrzeba sztucznego „odtworzenia” rozwiązań złożonych. Stało się to osią dalszej pracy naukowej i projektowej Alexandra. Początkowo chciał osiągnąć złożoność za pomocą programów generujących rozwiązania architektoniczne zależnie od potrzeb użytkowników ${ }^{12}$, a następnie katalogując „dobrze zaadaptowane" rozwiązania i formułując teorię wzorców ${ }^{13}$, co przyniosło mu sukces.

\section{INNE CECHY ZŁOŻONOŚCI W ARCHITEKTURZE}

Dla postmodernistów, którzy podjęli pozytywistyczny, naukowy paradygmat studiów nad architekturą, złożoność stała się fundamentalną cechą „zdrowej” przestrzeni. Akceptowanie wielości zjawisk i wpływów stało się oczywistą cechą współczesnej urbanistyki. Poszerzył się też zestaw pojęć charakteryzujących złożoność przestrzeni. Alexander wprowadził strukturę 
„sieci” jako modelu organizacji złożonej hierarchii ${ }^{14}$, co podjął m.in. Lucien Kroll w The Architecture of Complexity (pl. Architektura złożoności, 1987) ${ }^{15}$. Ci sami autorzy zwracają uwagę na partycypację jako prosty „manewr” zwiększający złożoność procesu projektowego przez adaptowanie rozwiązań do potrzeb poszczególnych użytkowników ${ }^{16}$. Adaptacyjność (dialogiczność) jest cechą, która doprowadziła do licznych analogii z przyrodą, otwierając drogę dla teorii architektury naturalnej (np. Kisho Kurokawa ${ }^{17}$, Itsuko Hasegawa ${ }^{18}$ czy Nikos Salingaros i Michael Mehaffy ${ }^{19}$ ). Ta sama właściwość stała się też podstawą fascynacji architekturą wernakularną i historyczną, zgodnie z powszechnym w postmodernizmie przekonaniem, że złożone procesy (tradycyjne i historyczne) generowały złożone, „żywe” formy.

Analiza form leżała w centrum zainteresowania fizyka i matematyka Nikosa Salingarosa ${ }^{20}$. Analizował on „wizualną” złożoność architektury, posługując się aparatem badawczym opartym na teorii złożoności obliczeniowej ${ }^{21}$. Złożoność w sensie obliczeniowym wykazuje cechy wspólne z teorią systemów złożonych, stanowiąc w pewnym sensie inną metodę opisu tych samych zjawisk. Ujmując rzecz w dużym przybliżeniu, jest ona miarą trudności danego zadania. Mierzy się ją np. czasem potrzebnym do wykonania zadania przez standardowy, uniwersalny komputer lub długością najkrótszego możliwego programu potrzebnego do wykonania tego zadania22. Przełożenie tej kategorii na przedmioty i procesy fizyczne opiera się na pomiarze złożoności opisu (modelu) danego obiektu. Obiekt lub proces jest złożony, jeśli taki jest jego opis ${ }^{23}$. Prosty przykład ilustrują poniższe rysunki, przedstawiające krzywe na siatce i opis ich przebiegu w postaci ciągu liczbowego. Ciąg zaczyna się zerem, każda kolejna liczba 0 oznacza, że linia kontynuuje kierunek, który miała w poprzedniej kratce, zaś 1 oznacza zmianę kierunku.

Przebieg prostej $a$ jest możliwy do opisania bardzo prostą formułą (generatorem), nieznacznie dłuższą można opisać krzywą $b$. Z kolei najkrótszym możliwym generatorem przebiegu chaotycznej (lub losowej) krzywej $c$ jest jej cały opis. Nawet jego uproszczenie daje niewiele, ponieważ lokalne regularności $(0,1)$ i $(0,0)$ pojawiają się w przypadkowej kolejności. Z kolei opis krzywej $d$ daje się zwięźle uprościć, składa się bowiem w rzeczywistości z krótszych ciągów uporządkowanych hierarchicznie. Murray Gell-Mann, laureat Nagrody Nobla z fizyki (1969), definiuje efektywną złożoność (ang. effective complexity) jako stan pośredni pomiędzy prostotą a chaosem, taki, w którym informacja jest właśnie efektywnie skompresowana. Gell-Mann zwraca uwagę na to, że pomiar złożoności przedmiotów rzeczywistych jest ściśle zależny od wielu czynników: kontekstu, obserwatora (np. ilości informacji, które może wprowadzić do opisu), poziomu zdefiniowania samej badanej wartości oraz poziomu detalu, do jakiego bada się złożoność obiektu (dokładność opisu - „ziarnistość" wg. Gell-Manna lub „rozdzielczość” wg. A.V. Moudon) ${ }^{24}$.

W rzeczywistości każda informacja może być opisana jako ciąg 0 i 1, w związku z tym teoretycznie możliwy jest opis każdego zjawiska w kategoriach prostoty, złożoności i chaotyczności. W przyrodzie obiektów i procesów dających się opisać ściśle (w znaczeniu zwięzłej formuły matematycznej, generatora) jest bardzo niewiele ${ }^{25}$. Z tego i innych powodów postulat 
ścisłej, „policzalnej” złożoności form architektonicznych Salingarosa może być uznany za kontrowersyjny ${ }^{26}$. Wydaje się jednak, że słusznie zwraca on uwagę na fakt, że ludzki mózg dobrze reaguje na pewne konkretne, wysokie poziomy złożoności, obserwowalne w naturze i architekturze historycznej. Tę cechę postrzegania nazywa biofilią. Innym problemem jest jednak sposób przyswajania złożoności przez obserwatora - tak jak widzimy fraktal w paprotce, chociaż w rzeczywistości jej kształt jest jedynie przybliżeniem fraktala, tak postrzegamy złożoność w systemach, które zawierają zaledwie niektóre jej cechy. Ważnym wkładem w ten aspekt badań jest „ograniczona złożoność” wprowadzona przez Juliusza Żórawskiego jako ilość złożoności „przyswajalnej” przez obserwatora ${ }^{27}$. Można argumentować, że hierarchiczność obiektów i procesów ułatwia przyswajalność informacji, dlatego percepcyjna teoria ograniczonej złożoności Żórawskiego również mieści się w ramach ogólniejszej teorii systemów złożonych.

\section{PODSUMOWANIE - KWESTIA KLASYFIKACJI}

Teoria systemów złożonych (czy szerzej: teoria złożoności) stanowi adekwatne narzędzie do precyzyjnego opisu różnorodnych zjawisk w obszarze wiedzy o architekturze, pozwalając na analizę zjawisk architektury jako „odzwierciedlenia zachowań skomplikowanego systemu adaptacyjnego"28. Za sprawą Venturiego i Alexandra stała się, obok m.in. badań nad znaczeniami, jedną z podstaw nowoczesnej, postmodernistycznej teorii architektury. Dotychczas w tej dziedzinie brak jednak spójności i systematyczności, zwłaszcza w zakresie poprawnej klasyfikacji zagadnień poddawanych analizom. Jeśli spojrzeć na problem pod tym kątem, należy przede wszystkim zadać sobie pytanie: jakie zagadnienia w obrębie wiedzy o architekturze mogą być opisywane i analizowane w kategoriach teorii złożoności? Odpowiedź na to pytanie jest jednym ze sposobów efektywnej klasyfikacji problemów.

Analiza samych przytoczonych pozycji literatury sugeruje przynajmniej niektóre kategorie, które mogłyby się w takiej klasyfikacji znaleźć. Nikos Salingaros zajmuje się głównie zagadnieniami geometrii i analizuje złożoność form architektonicznych. Badania tego typu zdają się być najbardziej rozpowszechnione - formy geometryczne łatwo poddają się matematycznej analizie pod kątem złożoności, a tradycyjnie stanowią przecież kluczowy ośrodek zainteresowania architektów. Mamy więc do czynienia ze złożonością form (lub kompozycji) składających się na architekturę.

Jednocześnie wydaje się, że Venturi, pisząc o wyższym stopniu złożoności Wiley House Johnsona w stosunku do Glass House tego samego architekta, nie bierze pod uwage jedynie złożoności w sensie geometrycznym. Wspomina o trafnym oddaniu charakteru poszczególnych części budynku pełniących różne funkcje ${ }^{29}$. Tym samym daje do zrozumienia, że złożoność budynku zależy od wielu jego cech, nieraz niepoddających się analizie matematycznej. Ten najważniejszy, intuicyjny rodzaj złożoności architektury umyka pomiarowi. 
Może z pomocą przychodzi tutaj teoria złożoności obliczeniowej: złożoność budynku „mierzona" jako stopień złożoności jego najkrótszego możliwego opisu? Jak miałby wyglądać taki opis, aby dać nam jakąkolwiek szansę obiektywnego „pomiaru”, uwzględniając jednocześnie „miękkie” cechy architektury30? Opisy w języku naturalnym zasadniczo nie nadają się do badania w kategoriach złożoności. Dotykamy tutaj zagadnienia samej analizy - bez trafnego języka analizy architektury nie sposób badać jej złożoności. Rozumiał to Alexander, starając się przeprowadzać „dekompozycję” projektu ${ }^{31}$ czy wprowadzając opis architektury w kategoriach wzorców, aby uprościć i usystematyzować relacje w budynku w postaci grafu².

Innym sposobem myślenia o opisie architektury jest opis w kategoriach programu: złożony program generujący plany, opisany przez Alexandra w Houses Generated by Patterns niewątpliwie daje rezultat w postaci bardziej złożonej (mniej poddającej się prostemu opisowi) architektury. Nie każdy obiekt architektury jest jednak generowany programem lub nawet projektem. Postmoderniści długo argumentowali, że ewolucyjny charakter przekształceń miasta daje efekt w postaci złożonej, niedającej się łatwo usystematyzować architektury i urbanistyki. Przekształcenia miasta czy budynku w czasie, drobne adaptacje użytkowników, partycypacja i zdarzenia losowe sugerują, że sam proces powstawania budynku może być analizowany w kategoriach złożoności. To właśnie efekty ewolucyjnego procesu powstawania miasta starali się sztucznie odtworzyć Alexander czy Kroll w projekcie ZUP Perseigne w Alençon. Swego rodzaju „przedłużeniem” tego procesu jest ciągłość tradycji architektonicznej - kolejnego zagadnienia wykazującego cechy złożone.

Sukcesy teorii złożoności w trafnym opisie różnorodnych zjawisk (począwszy od ewolucji organizmów, poprzez badania pogody, a skończywszy na zachowaniu giełdy) pobudziły nadzieje, że stanie się ona solidnym fundamentem interdyscyplinarnych badań odnajdujących makrozwiązki pomiędzy dziedzinami dotąd tradycyjnie uznawanymi za oddzielne ${ }^{33}$. Jej ramy merytoryczne nigdy nie zostały precyzyjnie wyznaczone, co wciąż stanowi istotną barierę w rozwoju i bolączkę zajmujących się nią naukowców ${ }^{34}$. Badając różnorodność zagadnień w obszarze jednej tylko dziedziny, architektury, można zrozumieć genezę tego problemu. Istnieje jednak głęboko zakorzeniona w postmodernizmie tradycja analizowania architektury w kategoriach złożoności. Problemem, z którym przyjdzie się zmierzyć teraz teoretykom, jest klasyfikacja różnorodnych zagadnień złożonych w obrębie architektury i opisanie ich, w dalszej zaś kolejności badanie związków pomiędzy nimi. Precyzyjny język i metodologia są kluczem do analizy złożoności - zwłaszcza teraz, w czasach, gdy słowo to staje się coraz powszechniej nadużywane. 

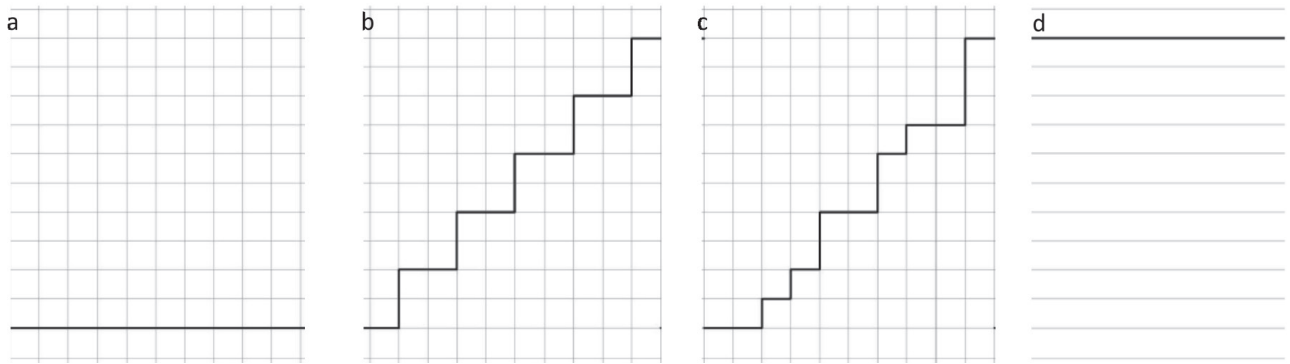

II. 1. Krzywe i opis ich przebiegu

$A=(0,0,0,0,0,0,0,0,0,0,0)$

$\mathrm{B}=(0,1,0,1,0,1,0,1,0,1,0,1,0,1,0,1,0,1,0,1)$

$\mathrm{C}=(0,0,1,1,1,1,1,0,1,0,1,0,1,1,1,0,1,0,0,1)$

lub $A=(0,0, \ldots, 0),|A|=10$

lub $B=(0,1,0,1, \ldots, 1),|B|=20$

lub $\mathrm{C}=(0, a, b, b, a, a, a, b, a, 0, a)$

lub $a_{n}=0, n \in N,|A|=10$

lub $a_{n}=0, n \in N P, a_{n}=1, n \in P,|B|=20$

$a=(0,1), b=(1,1) \mathrm{D}=(0,1,0,0,0,0,0,0,0$ , $0,1,0,1,1,1,1,1,1,1,0,1,1,1,1,1,1,1,1,0,1,0,1,0,0,0,0,0,0,0,0,0,1,0,1,1,1,1,1,1,1,0,1,1,1,1,1,1,1,1,0,0,0,0,0,0,0,0,0$, $0,1,0,1,1,1,1,1,1,1,0,1,1,1,1,1,1,1,0,1)$ lub $\mathrm{D}=(a, a, \ldots), a=(m, h, h), m=(0,1,0,0,0,0,0,0,0,0,0,1,0,1), h=(1,1,1,1,1,1,0,1)$

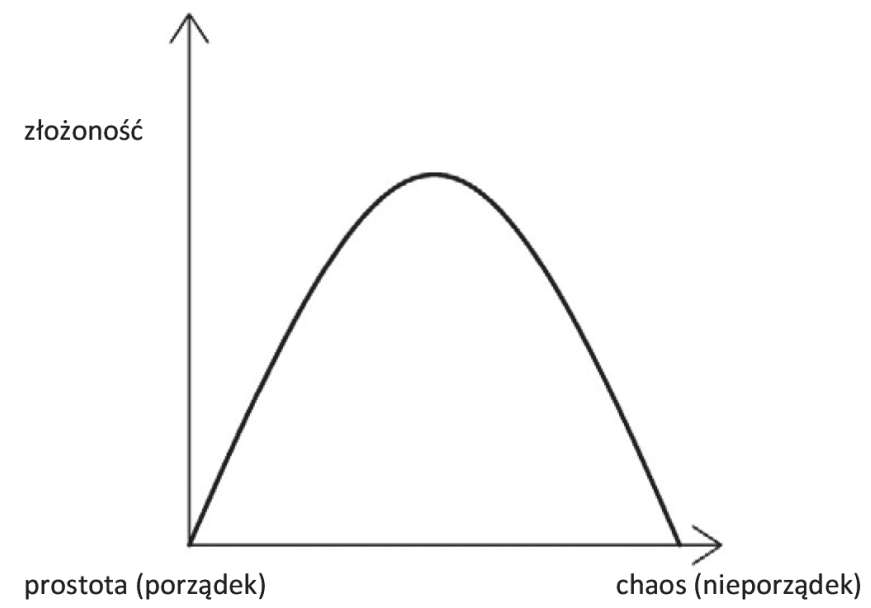

II. 2. Relacja prostoty, złożoności i chaotyczności

(wg. Tambor, Szydłowski, Złożoność; Gell-Mann, What is complexity?; aut. Michał Żyła) 


\section{PRZYPISY}

1 Por. Le Corbusier, W stronę architektury, tłum. T. Swoboda, Centrum Architektury, Warszawa 2012.

2 R. Venturi, Complexity and Contradiction in Architecture, Museum of Modern Art, Nowy Jork 1966, 1977, s. 16.

3 Oficjalna strona Nagrody Turinga, https://amturing.acm.org/award_winners/simon_1031467.cfm (dostęp: 15.04.2019).

4 Ch. Alexander, Notes on the Synthesis of Form, Harvard University Press, Cambridge, MA, 1964; R. Venturi, op. cit., s. 16.

5 H.A. Simon, The Architecture of Complexity, Proceedings of the American Philosophical Society, 106(6)/1962, s. 467, tłum. aut.

6 Ibidem.

7 Ididem, s. 468-479.

8 Ibidem, s. 469.

9 Alexander używa sformułowania unselfconscious cultures, co można tłumaczyć jako „kultury niesamoświadome” lub „kultury nieświadome siebie” (drugie tłumaczenie za: Teorie i manifesty architektury współczesnej, red. Ch. Jencks, K. Kropf, tłum. D. Szymczak, Sztuka Architektury, Warszawa 2013).

${ }^{10} \mathrm{Ch}$. Alexander, op. cit., s. 13-70.

${ }^{11}$ Eksperyment myślowy Alexandra z systemem lamp udowadnia właśnie cechę dekompozycji - por. M. Żyła, Język i rzeczywistość architektury, Fundacja im. Stefana Kuryłowicza, Warszawa 2016.

12 Ch. Alexander, S. Hirshen, S. Ishikawa, Ch. Coffin, Sh. Angel, Houses generated by patterns, Center for Environmental Structure, Berkeley 1969.

${ }^{13}$ Ch. Alexander, S. Ishikawa, M. Silverstein, M. Jacobson, I. Fiksdahl-King, Sh. Angel, Język wzorców. Miasta, budynki, konstrukcja, tłum. A. Kaczanowska, K. Maliszewska, M. Trzebiatowska, Gdańskie Wydawnictwo Psychologiczne, Gdańsk 2008.

${ }^{14}$ Ch. Alexander, Miasto to nie drzewo (A City is not a Tree) [w:] Teorie i manifesty..., op. cit., s. 50-52.

15 L. Kroll, Architektura złożoności [w:] Teorie i manifesty..., op. cit., s. 123-126.

${ }^{16}$ Ch. Alexander, S. Ishikawa, M. Silverstein, The Oregon Experiment, Oxford University Press, New York 1975; Kroll L., op. cit.

17 K. Kurokawa, Filozofia Symbiozy [w:] Teorie i manifesty..., op. cit., s. 129-131.

18 I. Hasegawa, Architektura jako inna natura [w:] Teorie i manifesty..., op. cit., s. 138-139.

19 M.W. Mehaffy, N.A. Salingaros, Design for a Living Planet. Settlement, Science and Human Future, Sustasis Press, Portland 2015. 
${ }^{20}$ Salingaros swoją twórczość w zakresie architektury zaczął od bliskiej współpracy z Alexandrem nad redakcją jego czterotomowej The Nature of Order (pl. Natura porzqdku, 2003-2004)

${ }^{21}$ N.A. Salingaros, A Theory of Architecture, Vajra Books, Kathmandu 2013.

22 Gell-Mann M., What is Complexity?, Complexity, 1(1)/1995, s. 16-19.

${ }^{23}$ Innymi słowy poziom złożoności obiektu lub procesu zależny jest od złożoności obliczeniowej programu pozwalającego na wygenerowanie (wg. niektórych autorów: wydrukowanie) najkrótszego możliwego opisu tego obiektu/procesu, por. Gell-Mann M., op. cit., s. 17.

24 Ibidem; A.V. Mouden, Urban morphology as an emerging interdisciplinary field, Urban morphology, 1/1997, s. 3-11. Przykładowo - krzywe b i c oglądane z bardzo dużej odległości będą wydawały się ukośnymi prostymi.

${ }^{25}$ K. Młynarski, Wybrane problemy teorii ewolucji, Wydawnictwo PiT, Kraków 2006, s. 90-91.

${ }^{26}$ Salingaros wprowadza do swojej teorii również aspekt "odczuwania" i znaczeń w architekturze. Tym samym wydaje się, że złożoność, o której pisze, dotyczy bardziej percepcji i indywidualnego odbioru architektury niż jakiejś jej obiektywnej właściwości.

27 K.J. Lenartowicz, Juliusza Żórawskiego pojęcie ograniczonej złożoności, Teka Komisji Urbanistyki i Architektury Oddział PAN w Krakowie, 44/2016, s. 79-87.

28 A. Mrozińska, Zagadnienie złożoności w problematyce badawczej przemysłu, Prace Komisji Geografii Przemysłu Polskiego Towarzystwa Geograficznego, 29(4)/2015, s. 26.

${ }^{29}$ R. Venturi, op. cit., s. 17.

30 Venturi przez większą część Complexity and contradiction... oddaje się problemowi „złożoności znaczeń”, sugerując, że znaczenia również poddają się analizie pod kątem złożoności. Wydaje się jednak, że na potrzeby tej części rezygnuje z używania słowa „złożoność” w znaczeniu ścisłym, zaczerpniętym od Simona, i poddaje się raczej ściśle filozoficznej analizie. Jakkolwiek istotna jest ta część z perspektywy architekta-humanisty, teoria znaczeń nie daje nam dostatecznie ścisłych narzędzi analizy, aby łączyć ją z teorią złożoności rozumianą tak, jak w tym tekście.

${ }^{31}$ Ch. Alexander, Notes on the Synthesis of Form, op. cit., s. 71-131, 136-173.

32 Idem, The Timeless Way of Building, Oxford University Press, Oxford 1979, s. 305-324.

33 P. Taborsky, Complexity [za:] PhilPapers, https://philpapers.org/browse/complexity (dostęp: 23.04.2019).

34 Idem, Is Complexity a Scientific Concept?, Studies in History and Philosophy of Science, 47/2014, part A, s. 51-59. 


\section{BIBLIOGRAFIA}

Alexander Ch., Notes on the Synthesis of Form, Harvard University Press, Cambridge, MA, 1964. Alexander Ch., The Timeless Way of Building, Oxford University Press, Oxford 1979.

Alexander Ch., Hirshen S., Ishikawa S., Coffin Ch., Angel Sh., Houses generated by patterns, Center for Environmental Structure, Berkeley 1969.

Alexander Ch., Ishikawa S., Silverstein M., The Oregon Experiment, Oxford University Press, New York 1975.

Alexander Ch., Ishikawa S., Silverstein M., Jacobson M., Fiksdahl-King I., Angel Sh., Język wzorców. Miasta, budynki, konstrukcja, tłum. A. Kaczanowska, K. Maliszewska, M. Trzebiatowska, Gdańskie Wydawnictwo Psychologiczne, Gdańsk 2008.

Gell-Mann M., What is Complexity?, Complexity, 1(1)/1995, s. 16-19.

Le Corbusier, W stronę architektury, tłum. T. Swoboda, Centrum Architektury, Warszawa 2012. Lenartowicz K.J., Juliusza Żórawskiego pojęcie ograniczonej złożoności, Teka Komisji Urbanistyki i Architektury Oddział PAN w Krakowie, 44/2016, s. 79-87.

Mehaffy M.W., Salingaros N.A., Design for a Living Planet. Settlement, Science and Human Future, Sustasis Press, Portland 2015.

Młynarski K., Wybrane problemy teorii ewolucji, Wydawnictwo PiT, Kraków 2006.

Mouden A.V., Urban morphology as an emerging interdisciplinary field, Urban morphology, 1/1997, s. 3-11.

Mrozińska A., Zagadnienie złożoności w problematyce badawczej przemysłu, Prace Komisji Geografii Przemysłu Polskiego Towarzystwa Geograficznego, 29(4)/2015, s. 26.

Oficjalna strona Nagrody Turinga, https://amturing.acm.org/award_winners/simon_1031467. cfm (dostęp: 15.04.2019).

Salingaros, N.A., A Theory of Architecture, Vajra Books, Kathmandu 2013.

Simon H.A., The Architecture of Complexity, Proceedings of the American Philosophical Society, 106(6)/1962.

Taborsky P. Complexity [za:] PhilPapers, https://philpapers.org/browse/complexity (dostęp: 23.04.2019).

Taborsky P., Is Complexity a Scientific Concept?, Studies in History and Philosophy of Science, 47/2014, part A, s. 51-59.

Teorie i manifesty architektury współczesnej, red. Ch. Jencks, K. Kropf, tłum. D. Szymczak, Sztuka Architektury, Warszawa 2013).

Venturi R., Complexity and Contradiction in Architecture, Museum of Modern Art, Nowy Jork 1966, 1977.

Żyła M., Język i rzeczywistość architektury, Fundacja im. Stefana Kuryłowicza, Warszawa 2016. 